\title{
Contact and oral toxicity to honey bees (Apis mellifera) of agents registered for use for sweet corn insect control in Ontario, Canada ${ }^{1}$
}

\author{
Janisse BAILEY ${ }^{\mathrm{a}}$, Cynthia SCOTT-DUPREE ${ }^{\mathrm{a} *}$, Ron HARRIS ${ }^{\mathrm{a}}$, Jeff TOLMAN ${ }^{\mathrm{b}}$, \\ Brenda HARRIS ${ }^{\mathrm{c}}$ \\ a University of Guelph, Department of Environmental Biology, Guelph, ON, Canada N1G 2W1 \\ b Agriculture and Agri-Food Canada, Southern Crop Protection and Food Research Center, 1391 Sandford St., \\ London, ON, Canada N5W 4T3 \\ ${ }^{c}$ Dow AgroSciences Canada Inc., \#201 - 1144 29th Av. N.E., Calgary, AB, Canada T2E 7P1
}

Received 12 August 2005 - revised 1 March 2005 - accepted 1 April 2005

Published online 15 November 2005

\begin{abstract}
Assays were conducted to compare direct and residual contact and oral toxicities to honey bees of sweet corn insecticides and of Bt-sweet corn. Direct contact assays focusing on $\mathrm{LC}_{50}$ determined that technical grade clothianidin was most toxic, $>$ carbofuran, $>$ imidacloprid $=$ spinosad, $>$ lambda-cyhalothrin, $>$ Bacillus thuringiensis. In residual contact assays, forager age bees were exposed to treated non-transgenic sweet corn tassels. Carbofuran treated tassels caused significant mortality up to 2 and 3 days after treatment (DAT) in 2002 and 2003, respectively. Lambda-cyhalothrin treated tassels had no impact on honey bees in 2002; in 2003, their toxicity was significantly higher than the untreated control tassels for 1 DAT. In both years, spinosad, imidacloprid and clothianidin or Bt-sweet corn tassels had no impact on honey bee mortality. Pollen collected from insecticide field treated corn and fed to honey bees had no impact on mortality.
\end{abstract}

Apis mellifera / sweet corn / foliar insecticides / seed treatment / Bt-sweet corn / toxicity

\section{INTRODUCTION}

Sweet corn, Zea mays L., is an important field vegetable in Ontario. The European corn borer (ECB), Ostrinia nubilalis (Hübner), is the most serious insect pest of sweet corn in North America (Mason et al., 1996). Currently, sweet corn growers rely almost exclusively on foliar insecticide treatments such as carbofuran and lambda-cyhalothrin for ECB control.

Another important pest of sweet corn is the corn flea beetle (CFB), Chaetocnema pulicaria Melsheimer, vector of Erwinia stewartii, the causal pathogen for the bacterial disease Stewart's wilt (Pepper, 1967). Stewart's wilt has been managed by planting resistant sweet corn varieties. Recently, there has been increasing interest in using sweet corn grown from seed treated with insecticide or Bt-sweet corn to control CFB (Pataky et al., 2000).

Depending on regional conditions, sweet corn can be an attractive pollen source for honey bees. Sweet corn plants can produce in excess of $170 \mathrm{~kg}$ of pollen per hectare, making this crop a useful protein source for bees, especially during dry growing seasons, or periods of dearth, when more favorable protein sources may not be available (Nowakowski and Morse, 1982). Foliar applications of carbofuran (FURADAN ${ }^{\circledR} 480 \mathrm{~F}$ ) are suspected of causing significant kills of bees foraging in treated sweet corn fields in Ontario (Oliver, 1999).

\footnotetext{
* Corresponding author: cscottdu@uoguelph.ca
}

${ }^{1}$ Manuscript editor: Jean-Noël Tasei 
Imidacloprid (GAUCHO $\left.{ }^{\circledR} 480 \mathrm{FS}\right)$, used as a seed treatment for CFB control also has been investigated as a result of concerns raised in Europe and Canada in 1996 regarding possible impact on bees foraging in imidacloprid treated crops (Schmuck et al., 2001; Scott-Dupree and Spivak, 2001).

Potential pesticide poisoning from treated sweet corn has long concerned beekeepers in North America. The critical time for ECB control is between late whorl and crop tasseling or silking (Ditman and Lloyd, 1951; Harrison and Press, 1971), a period which encompasses pollen shed. In addition, while incidence of Stewart's wilt is effectively reduced by controlling CFB with systemic insecticide seed treatments (Munkvold et al., 1996; Pataky et al., 2000; Kuhar et al., 2002), it is possible that residues of those insecticides may be toxic to bees. Improved management practices have minimized insecticide use and increased awareness of the problem. Unfortunately, despite all mitigating efforts, pesticide poisoning from treated sweet corn remains a serious concern for beekeepers.

Replacing foliar applied carbofuran with more selective control agents could effectively reduce bee kills. Recently registered insecticides such as spinosad (SUCCESS ${ }^{\circledR} 480$ SC), clothianidin (PONCHO ${ }^{\circledR} 600 \mathrm{~F}$ ), and sweet corn genetically engineered to express Bacillus thuringiensis Berliner (Bt) endotoxin Cry $1 \mathrm{AB}$ (ATTRIBUTE $^{\mathrm{TM}}$ ) have been reported to effectively control ECB and CFB (Burkness et al., 2001; Scott-Dupree et al., 2001; Andersch and Schwarz, 2003; Bailey et al., 2005). To investigate the potential risk associated with use of carbofuran, lambda-cyhalothrin, imidacloprid, clothianidin, spinosad and Bt-sweet corn, we assessed the direct, residual contact and oral toxicities of these pest control agents to honey bees.

\section{MATERIALS AND METHODS}

\subsection{Direct contact assays}

Four honey bee (Apis mellifera L.) colonies containing open mated sister queens (2001, Buckfast, PM10-F1) were established on May 6, 2003 at the Agriculture and Agri-Food Canada (AAFC) - Southern Crop Protection and Food Research Centre (SCPFRC), London, Ontario. Colonies were examined for presence of Varroa destructor Anderson and Trueman and Acarapis woodi (Rennie) prior to use and it was determined that the mites were present at very low levels $(<10 \%)$. Colonies were free of all other honey bee related bacterial and fungal diseases that can occur in Canada.

To investigate direct contact toxicity of the insecticides, we used technical grade material $(95 \%$ purity). The pure Bt endotoxin Cry1 $\mathrm{AB}$ present in Bt-sweet corn was not available so DIPEL ${ }^{\circledR} 2 \mathrm{X} \mathrm{DF}$ (Valent BioSciences Canada, Ltd.), the active ingredient of which is Bacillus thuringiensis, subsp. kurstaki (Strain HD-1, 32000 International Units of potency per $\mathrm{mg}$ ), was subsituted. Test solutions $(1.0 \% \mathrm{w} / \mathrm{v})$ were prepared by dissolving each insecticide in 19:1 acetone:olive oil. With DIPEL and spinosad, reverse-osmosis (RO) water was used. Each insecticide was tested at 4-5 concentrations ranging from $0.00008-1.0 \%$ solution. Controls were treated with the solvent mixture. Cohorts of 20 forager age ( $>20$ day old) bees were collected from the colonies. The bees were anaesthetized with $\mathrm{CO}_{2}$ for $3 \mathrm{~s}$, transferred to a $9 \mathrm{~cm}$ glass petri dish and placed in a Potter spray tower (Potter, 1952) where they were sprayed with $5 \mathrm{~mL}$ aliquots of each insecticide solution as described by Harris and Svec (1969). Treated bees were then divided into 2 groups of 10 and held in waxed paper cups covered with glass lids. Each cup was provided with 2 cotton wicks $(2 \mathrm{~cm}$ long $\times 0.9 \mathrm{~cm}$ diam.) soaked in $1: 1(\mathrm{v} / \mathrm{v})$ honey:water solution, and a Bee Boost ${ }^{\circledR}$ strip containing 0.4 Queen Mandibular Pheromone (QMP) equivalents, to maintain cohesion of the bees in small clusters. The cups were kept at $27 \pm 1{ }^{\circ} \mathrm{C}$ and $65 \pm 5 \%$ relative humidity (RH) in darkness. The number of dead bees per cage was counted $24 \mathrm{~h}$ after exposure. Control mortality never exceeded $10 \%$.

\subsection{Residual contact assays with corn tassels}

In 2002 and 2003, 10 honey bee colonies containing naturally mated sister queens (2001, Buckfast, PM10-F1) were established at the University of Guelph - Townsend House Bee Research Facility (THBRF), Guelph, Ontario. The colonies had the same health profile as described for those in Section 2.1. Cohorts of 25 pollen-bearing forager age bees were collected from the colony entrance into a $250 \mathrm{~mL}$ glass jar attached to a modified Dust

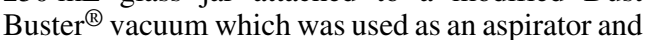
were transferred to a $3.75 \mathrm{~L}$ glass jar. The opening was covered with a $17 \times 17 \mathrm{~cm}$ piece of mesh fly screening held in place with an elastic. Pollen shedding test tassels were collected from non-transgenic sweet corn (cultivar (cv.) Precious gem) grown in field trials at the University of Guelph - Cambridge Research Station (CRS) in 2002, and at the AAFC Delhi Research Farm (DRF), Delhi, Ontario in 2002 
Table I. Application rates of sweet corn pest management agents tested for residual and oral toxicity to adult honey bees in laboratory bioassays.

\begin{tabular}{lccc}
\hline Year & Insecticide & Formulation & Rate Applied (a.i.) \\
\hline Foliar treatments 2002 & carbofuran & FURADAN $^{\circledR} 480 \mathrm{~F}$ & $530 \mathrm{~g} / \mathrm{ha}$ \\
& lambda-cyhalothrin & MATADOR $^{\mathrm{TM}} 120 \mathrm{EC}$ & $10 \mathrm{~g} / \mathrm{ha}$ \\
& spinosad & SUCCESS $^{\circledR} 480 \mathrm{SC}$ & $70 \mathrm{~g} / \mathrm{ha}$ \\
Seed treatment 2002 & imidacloprid & GAUCHO $^{\circledR} 480 \mathrm{FS}$ & $1.6 \mathrm{~g} / \mathrm{kg}$ seed \\
Foliar treatments 2003 & carbofuran & FURADAN $^{\circledR} 480 \mathrm{~F}$ & $530 \mathrm{~g} / \mathrm{ha}$ \\
& lambda-cyhalothrin & MATADOR $^{\mathrm{TM}} 120 \mathrm{EC}$ & $10 \mathrm{~g} / \mathrm{ha}$ \\
& spinosad & SUCCESS $^{\circledR} 480 \mathrm{SC}$ & $40 \mathrm{~g} / \mathrm{ha}$ \\
Seed treatments 2003 & imidacloprid & GAUCHO $^{\circledR} 480 \mathrm{FS}$ & $2.5 \mathrm{~g} / \mathrm{kg}$ seed \\
& clothianidin & PONCHO $^{\circledR} 600 \mathrm{~F}$ & $1.25 \mathrm{mg} / \mathrm{kernel}$ \\
\hline
\end{tabular}

and 2003. This sweet corn had been treated with carbofuran, lambda-cyhalothrin, spinosad, imidacloprid or clothianidin at recommended field rates (Tab. I). Treatment plots at each site were replicated 4 times in a randomized complete block design. Tassels from transgenic (expressing the Cry1 Ab Btendotoxin (var. BC 0801)) sweet corn were collected from an adjacent block. Honey bees were exposed to test tassels collected from non-transgenic sweet corn treated with the foliar insecticides carbofuran, lambda-cyhalothrin and spinosad $12 \mathrm{~h}$ prior to treatment (Pre-Trt) and $12 \mathrm{~h}$ (Day 1), $36 \mathrm{~h}$ (Day 2), and $60 \mathrm{~h}$ (Day 3) after treatment. Tassels harvested from non-transgenic sweet corn grown from imidacloprid and clothianidin treated seed and Bt-sweet corn were collected at the start of pollen shed (Day 1) and for 3 consecutive days (Days 2, 3 and 4). The control treatment consisted of tassels collected from untreated non-transgenic sweet corn at the same time that tassels from the foliar insecticide treated sweet corn were collected. Treatments from each collection day were replicated 4 times. The jars were provisioned with a water and carbohydrate solution $(1: 1 \mathrm{w} / \mathrm{v}$ sugar:water) ad libitum via gravity feeders and a Bee Boost ${ }^{\circledR}$ strip containing 0.4 QMP equivalents and were held at $27 \pm 1{ }^{\circ} \mathrm{C}$ and $65 \pm 5 \% \mathrm{RH}$ in $24 \mathrm{~h}$ darkness. The number of dead bees per cage was counted $24 \mathrm{~h}$ after exposure. Control mortality never exceeded $10 \%$.

\subsection{Oral assays with corn pollen}

In 2002 and 2003, frames containing sealed brood were obtained from 10 colonies containing naturally mated sister queens (2001, Buckfast, PM10-F1) maintained at the THBRF. The colonies had the same health profile as described earlier. Frames were incubated at $33 \pm 1{ }^{\circ} \mathrm{C}$ and $85 \pm 5 \% \mathrm{RH}$. Cohorts of 20 newly emerged bees ( $<24 \mathrm{~h}$ old) were collected from frames and placed in wooden cages $(11 \times 8 \times 13 \mathrm{~cm})$ with wire screened bottoms and glass fronts. Pollen was collected from non-transgenic sweet corn (cv. Precious gem) grown in field trials at the CRS in 2002 and at the DRF in 2002 and 2003. This sweet corn had been treated with carbofuran, lambda-cyhalothrin, spinosad, imidacloprid or clothianidin at recommended field rates (Tab. I). To reduce moisture accumulation, test pollen was collected in Showerproof ${ }^{\circledR}$ \# 504 tassel bags and transported to the THBRF in Drierite ${ }^{\circledR}$ lined coolers. To remove potential contaminants, test pollen was sieved through \# 20,120 and 240 mesh plastic sieves. Transgenic pollen was collected from an adjacent Bt-sweet corn block. Pollen from sweet corn treated with the foliar insecticides carbofuran, lambda-cyhalothrin and spinosad was collected $12 \mathrm{~h}$ prior to treatment (Pre-Trt) and $12 \mathrm{~h}$ (Day 1), $36 \mathrm{~h}$ (Day 2), and 60 h (Day 3) after treatment. Pollen from sweet corn grown from imidacloprid and clothianidin treated seed and Bt-sweet corn was collected at the start of pollen shed (Day 1) and for 3 consecutive days (Days 2, 3 and 4). The control treatment consisted of pollen collected from untreated non-transgenic sweet corn at the same time that collections were made from the foliar insecticide treatments. Treatments from each collection day were replicated 4 times. Each cage of bees was provisioned and kept as described in Section 2.2. The 
Table II. Direct contact toxicity to adult forager age honey bees of several insecticides used for European corn borer (Ostrinia nubilalis (Hübner)) or corn flea beetle (Chaetocnema pulicaria (Melsheimer)) control on sweet corn.

\begin{tabular}{lccccc}
\hline Treatment & $\mathrm{n}^{1}$ & Slope $\pm \mathrm{SEM}$ & $\mathrm{LC}_{50}{ }^{2}$ & $95 \% \mathrm{FL}^{3}$ & $\chi^{24}$ \\
\hline clothianidin & 311 & $2.6 \pm 0.5$ & $0.2 \mathrm{~d}^{5}$ & $0.1-0.3$ & 1.2 \\
carbofuran & 294 & $3.0 \pm 0.5$ & $1.0 \mathrm{c}$ & $0.8-1.2$ & 3.2 \\
imidacloprid & 259 & $2.8 \pm 0.6$ & $2.2 \mathrm{~b}$ & $1.5-2.6$ & 0.4 \\
spinosad & 274 & $7.0 \pm 1.4$ & $2.2 \mathrm{~b}$ & $1.8-2.5$ & 0.7 \\
lambda-cyhalothrin & 414 & $4.9 \pm 0.6$ & $3.1 \mathrm{a}$ & $2.9-3.4$ & 4.5 \\
Bacillus thuringiensis & 160 & -6 & $>1000$ & - & - \\
(DIPEL ${ }^{\circledR}$ 2X DF) & & & & & \\
\hline
\end{tabular}

1 Total number (n) of adult bees evaluated.

2 Concentrations are expressed as $\%$ solution $(\mathrm{w} / \mathrm{v})\left(\times 10^{-3}\right)$.

3 Fiducial limits $\left(\times 10^{-3}\right)$

4 Chi square values.

5 Values followed by the same letters are not significantly different as determined by overlap of $95 \%$ Fiducial limits.

${ }^{6}$ No mortality at highest concentration tested (> $1.0 \%$ solution).

number of dead bees per cage was counted $24 \mathrm{~h}$ after exposure. Control mortality never exceeded $10 \%$.

\subsection{Residue analysis}

In 2003, pollen and plant tissue (anthers) samples were analyzed for residues of the foliar insecticides, carbofuran, lambda-cyhalothrin and spinosad. Samples were collected from non-transgenic sweet corn (cv. Precious gem) grown in field trials at the DRF. To remove potential contaminants and separate pollen and anthers, samples were sieved through \# 20, 120 and 240 plastic sieves. Three g samples were placed in amber glass jars and maintained in a freezer at $-80 \pm 2{ }^{\circ} \mathrm{C}$ until shipment to Enviro-Test Laboratories (Edmonton, Alberta) on September 15, in a dry-ice provisioned Styrofoam ${ }^{\circledR}$ cooler, where residue analyses were conducted. Nectar and pollen samples from carbofuran and lambda-cyhalothrin treated sweet corn were extracted by polytron blending with methanol and water, concentrated using a roto evaporator and the extract was eluted through a ChemElute (CE 1020) column. The pollen samples were passed through a silica gel clean-up column. All samples were then analyzed by High Performance Liquid Chromatography-Electronspray Ionization Mass Spectrometry (HPLC-MS/MS). The level of detection for carbofuran and lambda-cyhalothrin in pollen and plant tissue was $0.02 \mathrm{mg} / \mathrm{kg}$. Spinosad samples were analyzed using a standard protocol EPA 8151-GC/MS. The level of detection for spinosyns $\mathrm{A}, \mathrm{B}, \mathrm{K}$ and $\mathrm{D}$ in pollen and plant tissue was $0.001 \mathrm{mg} / \mathrm{kg}$.

\subsection{Data analysis}

Mortality data (\%) from direct contact assays were corrected for natural mortality using Abbott's formula (Abbott, 1925). For each insecticide, regression lines, $\mathrm{LC}_{50}$ values, $95 \%$ fiducial limits (FL) and $\chi^{2}$ goodness of fit were determined using a log-probit analysis program (S103, Statistical Research Services, AAFC).

Mortality data from residual contact and oral assays were arcsine square root transformed. Statistical significance of differences among treatments was determined using either analysis of variance (ANOVA) and a Fisher's Protected LSD for mean separation, or Student's t-test.

\section{RESULTS}

\subsection{Direct contact assays}

Technical grade clothianidin was most toxic by direct contact $>$ carbofuran $>$ imidacloprid $=$ spinosad $>$ lambda-cyhalothrin $>$ Bt (Tab. II). Clothianidin and carbofuran were significantly more toxic than the other insecticides. Spinosad and imidacloprid were intermediate in toxicity, lambda-cyhalothrin was significantly less toxic than the other chemicals and Bt was nontoxic, even at $1.0 \%$ solution (Tab. II). 
a)

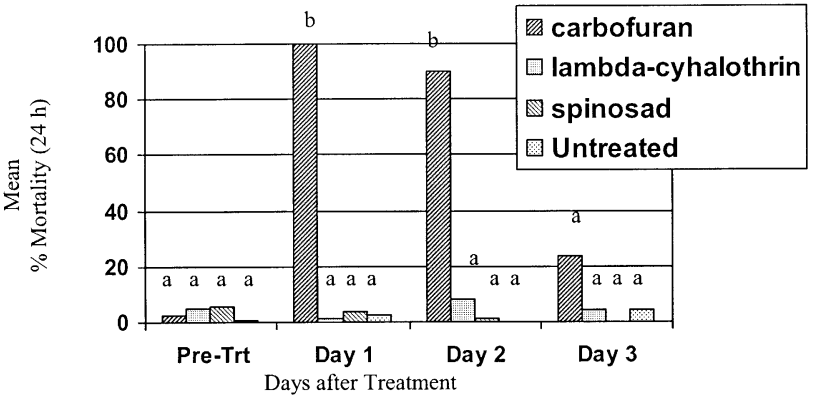

b)

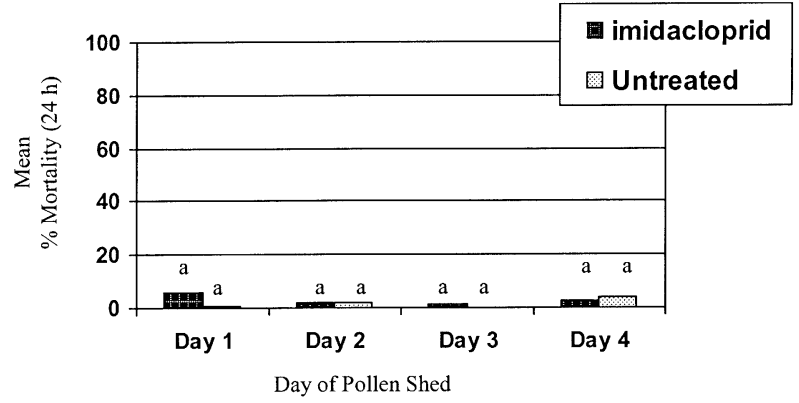

c)

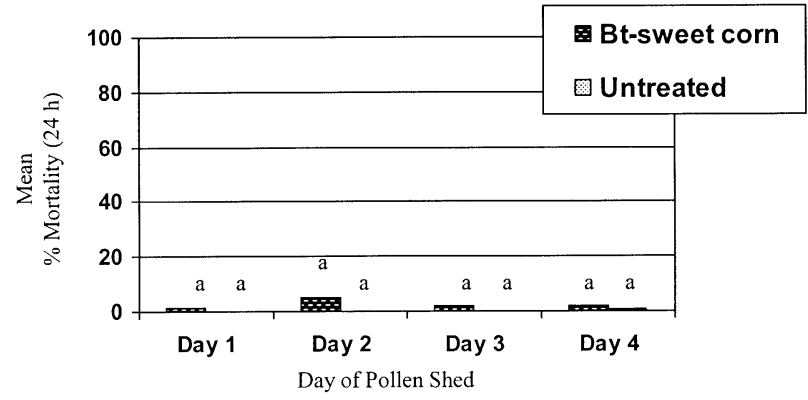

Figure 1. Residual contact toxicity to adult forager age honey bees of pollen shedding sweet corn tassels collected at the Cambridge Research Farm treated with (a) the foliar insecticides - carbofuran, lambda-cyhalothrin or spinosad; (b) the seed treatment insecticide - imidacloprid; and, (c) Bt sweet corn engineered to express the Bt-endotoxin, Cry $1 \mathrm{AB}$ (var. BC 0801), 2002. Bars followed by the same letter are not significantly different for any given day as determined by ANOVA and Fisher protected LSD $(P<0.05)$ or a Student's t-test $(P<0.05)$.

\subsection{Residual contact assays}

In 2002, residual contact toxicity to honey bees of carbofuran treated tassels, was significantly higher than that of lambda-cyhalothrin or spinosad treated tassels for up to 2 days after treatment (DAT) (Figs. 1a and 2a). All bees died when exposed to carbofuran treated tassels collected from both field sites 1 DAT. Eightyeight and $73 \%$ of the bees died when exposed to tassels collected 2 DAT from the CRS and the DRF, respectively. Tassels treated with spinosad or lambda-cyhalothrin at both locations, had no impact on honey bee mortality (Figs. 1a and 2a).

There was no significant mortality when honey bees were exposed to tassels collected from plants grown from imidacloprid treated seed or from Bt-sweet corn (Figs. 1b, c and 2b, c). 
a)

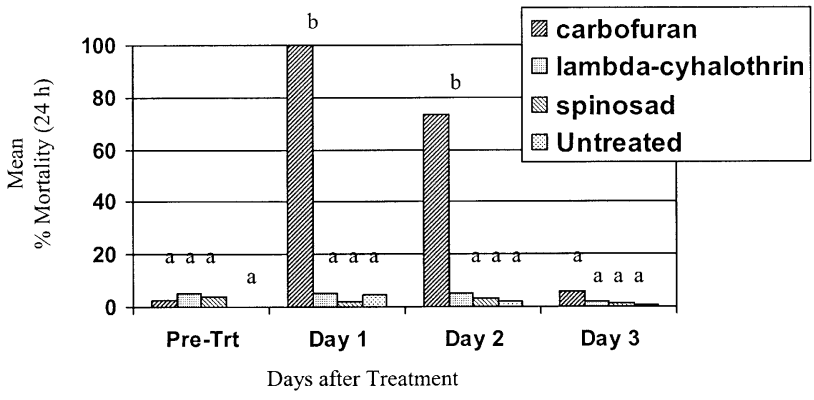

b)

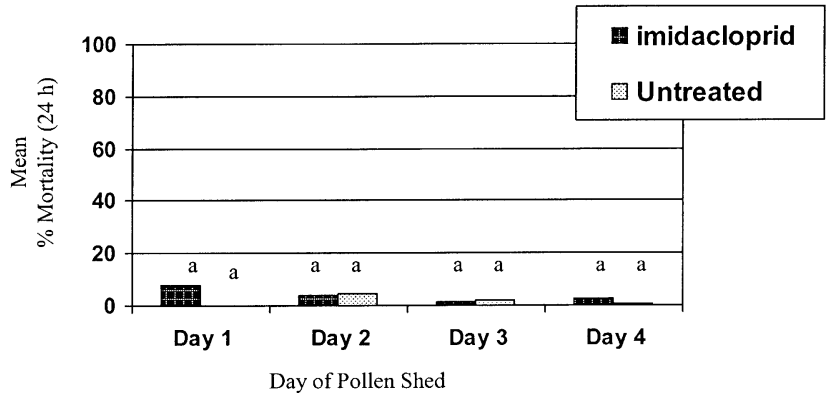

c)

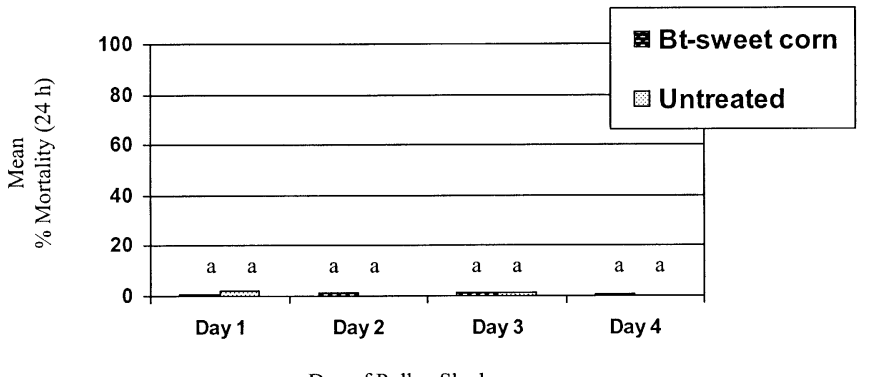

Day of Pollen Shed

Figure 2. Residual contact toxicity to adult forager age honey bees of pollen shedding sweet corn tassels collected at the Delhi Research Farm treated with (a) the foliar insecticides - carbofuran, lambda-cyhalothrin or spinosad; (b) the seed treatment insecticide - imidacloprid; and, (c) Bt sweet corn engineered to express the Bt-endotoxin, Cry1 AB (var. BC 0801), 2002. Bars followed by the same letter are not significantly different for any given day as determined by ANOVA and Fisher protected LSD $(P<0.05)$ or a Student's t-test $(P<0.05)$

In 2003, residual contact toxicity to honey bees of tassels collected from non-transgenic sweet corn grown at DRF and treated with carbofuran was significantly higher than that of tassels treated with lambda-cyhalothrin or spinosad for up to 3 DAT (Fig. 3a). All bees died when exposed to carbofuran treated tassels 1 DAT. Ninety-six and $74 \%$ of the bees died when exposed to tassels collected 2 and 3 DAT, respec- tively. Residual contact toxicity of tassels treated with lambda-cyhalothrin was significantly higher 1 DAT $(19.3 \%)$ than with those treated with spinosad (Fig. 3a), which had no significant impact on honey bee mortality. There was no significant mortality to honey bees when exposed to tassels collected from non-transgenic sweet corn grown from imidacloprid or clothianidin treated seed or from Bt-sweet corn (Fig. 3b, c). 
a)

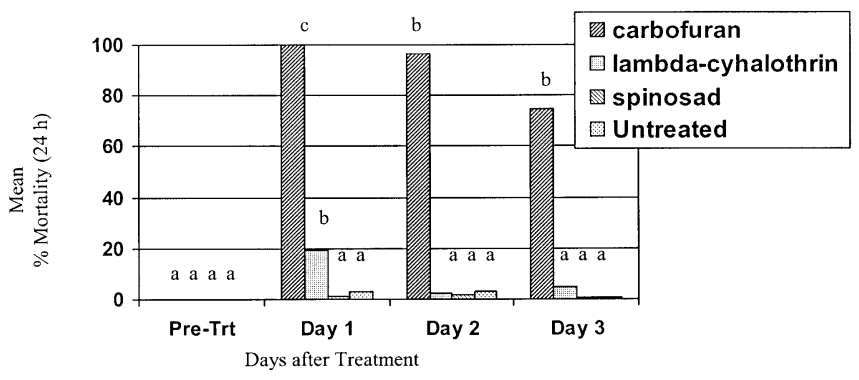

b)

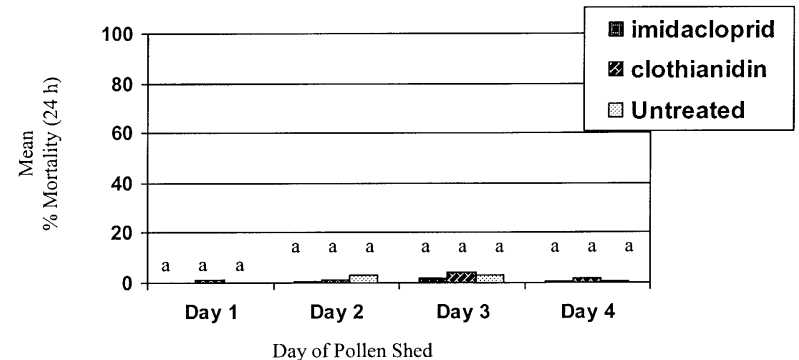

c)

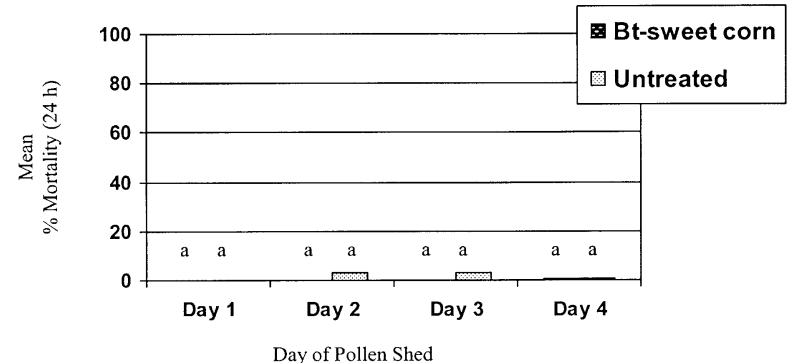

Figure 3. Residual contact toxicity to adult forager age honey bees of pollen shedding sweet corn tassels collected at the Delhi Research Farm treated with (a) the foliar insecticides - carbofuran, lambda-cyhalothrin or spinosad; (b) the seed treatment insecticides - imidacloprid or clothianidin; and, (c) Bt sweet corn engineered to express the Bt-endotoxin, Cry1 AB (var. BC 0801), 2003. Bars followed by the same letter are not significantly different for any given day as determined by ANOVA and Fisher protected LSD $(P<0.05)$ or a Student's t-test $(P<0.05)$.

\subsection{Oral assays}

No significant differences across treatments were apparent when newly emerged honey bees were fed pollen collected for sweet corn exposed to or grown from field applications of the foliar insecticides (carbofuran, lambda-cyhalothrin, spinosad), seed treatments (imidacloprid, clothianidin) or Bt-sweet corn (Tab. III).

\subsection{Residue analysis}

Plant tissue samples contained higher residues of carbofuran $(12 \mathrm{mg} / \mathrm{kg})$ than lambda-cyha- lothrin $(0.11 \mathrm{mg} / \mathrm{kg})$ or spinosad $(0.27 \mathrm{mg} / \mathrm{kg})$. Pollen samples also contained higher residues of carbofuran $(1.4 \mathrm{mg} / \mathrm{kg})$ than lambda-cyhalothrin $(<0.03 \mathrm{mg} / \mathrm{kg})$ or spinosad $(0.32 \mathrm{mg} / \mathrm{kg})$. With the exception of spinosad, insecticide residues were lower in pollen than in plant tissue (Tab. IV).

\section{DISCUSSION}

Results of the direct contact assays support findings reported elsewhere (e.g., Atkins et al., 1979; Halsall and Gray, 1998; Mayer et al., 
Table III. Oral toxicity to newly emerged honey bees of non-transgenic sweet corn pollen collected from plants treated with the foliar insecticides - carbofuran, lambda-cyhalothrin or spinosad, or the seed treatment insecticides - imidacloprid or clothianidin, or Bt sweet corn engineered to express the Btendotoxin Cry1AB (var. BC 0801), 2002 and 2003.

\begin{tabular}{|c|c|c|c|c|}
\hline \multirow[t]{3}{*}{ Treatment } & \multicolumn{4}{|c|}{ Mean \% Mortality (24 h) } \\
\hline & \multicolumn{2}{|c|}{2002} & \multicolumn{2}{|c|}{2003} \\
\hline & Pre-Trt ${ }^{1}$ & Day 1 & Pre-Trt & Day 1 \\
\hline carbofuran & $1.3 \mathrm{a}^{2}$ & $1.3 \mathrm{a}$ & $0.0 \mathrm{a}$ & $0.0 \mathrm{a}$ \\
\hline lambda-cyhalothrin & $0.0 \mathrm{a}$ & $0.0 \mathrm{a}$ & $0.0 \mathrm{a}$ & $0.0 \mathrm{a}$ \\
\hline spinosad & $0.0 \mathrm{a}$ & $2.5 \mathrm{a}$ & $1.3 \mathrm{a}$ & $0.0 \mathrm{a}$ \\
\hline imidacloprid & $0.0 \mathrm{a}$ & $0.0 \mathrm{a}$ & $0.0 \mathrm{a}$ & $0.0 \mathrm{a}$ \\
\hline clothianidin & $-^{3}$ & - & $0.0 \mathrm{a}$ & $1.3 \mathrm{a}$ \\
\hline Bt-sweet corn & $0.0 \mathrm{a}$ & $0.0 \mathrm{a}$ & $0.0 \mathrm{a}$ & $0.0 \mathrm{a}$ \\
\hline untreated & $0.0 \mathrm{a}$ & $0.0 \mathrm{a}$ & $0.0 \mathrm{a}$ & $0.0 \mathrm{a}$ \\
\hline
\end{tabular}

${ }^{1}$ Pre-Trt equivalent to $12 \mathrm{~h}$ prior to applications of foliar insecticides; or the first day of pollen shed for seedtreated and Bt-sweet corn.

2 Means within the same column followed by the same letter are not significantly different as indicated by ANOVA and Fisher protected LSD comparison of means $(P<0.05)$.

3 Toxicity of clothianidin not evaluated in 2002 .

Table IV. Residues of carbofuran, lambdacyhalothrin and spinosad in non-transgenic sweet corn pollen and plant tissue collected from plants treated at the Delhi Research Station, 2003.

\begin{tabular}{lcc}
\hline Insecticide & $\begin{array}{c}\text { Plant Tissue } \\
(\mathrm{mg} / \mathrm{kg})\end{array}$ & Pollen $(\mathrm{mg} / \mathrm{kg})$ \\
\hline carbofuran & 12.0 & 1.40 \\
lambda-cyhalothrin & 0.11 & $<0.03$ \\
spinosad $^{2}$ & 0.27 & 0.32 \\
\hline
\end{tabular}

${ }^{1}$ Comprised of sweet corn anthers.

${ }^{2}$ Combination of spinosyns A and D.

1998; Schmuck et al., 2001; Schmuck and Keppler, 2003) that carbofuran, lambda-cyhalothrin, spinosad, imidacloprid and clothianidin are all highly toxic by direct contact to honey bees. However, while providing information on inherent insecticide toxicity, this laboratory data should not be accepted as the sole guideline for assessing risk associated with their use.

Under field conditions, insecticides will act very differently depending on many factors, particularly application rate and route of exposure. Direct contact toxicity probably has a minor role in causing bee toxicity since the impact of foliar insecticides would be confined to bees foraging in the field during application, while imidacloprid and clothianidin, registered for use on corn as seed treatments, would pose not direct contact risk.

Data obtained in the residual contact assays and residue studies demonstrate both the importance of this route of exposure and the marked differences that can occur between pesticides. When applied at recommended applications rates, carbofuran residue on plants tissue was ca. 40-100 $\times$ higher than spinosad and lambda-cyhalothrin. Tassels from carbofuran treated sweet corn showed significant biological activity for 2-3 days after treatment. While lambda-cyhalothrin showed only minimal activity and spinosad caused none. Imidacloprid and clothianidin seed treated corn also had no impact. Thus, of five insecticides, all highly toxic by direct contact, only one - carbofuran - demonstrated significant residual contact activity to bees when applied at the registered application rate.

Pollen contamination also could be an important route for honey bee exposure to insecticide residues. Although insecticide residues in the 
pollen from the foliar applied insecticides were, with exception of spinosad, from $<1 / 4$ to $1 / 8$ those found in plant tissue, the lack of oral toxicity was unexpected since all were toxic to bees in other oral feeding studies (Stoner et al., 1982; Halsall and Gray, 1998; Mayer et al., 1998). This lack of oral toxicity may have been due to the following characteristics of sweet corn and the pollen collection technique. Sweet corn is protected within anthers that extend well outside the plant floret via elongated filaments. A distal pore at the base of each anther allows pollen to escape when shaken by wind or disturbed by insects (Flottum et al., 1983). Honey bees forage $\mathrm{f}$ or sweet corn pollen by walking along the floret, bumping and moving the anthers and releasing pollen to fall on their bodies (Casteel, 1912). During foraging, pollen, once "protected" by the anther from contamination, comes into contact with pesticide residues on floret surfaces. Our collection technique involved shaking treated sweet corn tassels in bags allowing the pollen to fall freely, providing little opportunity for the pollen sample to become contaminated.

The lack of oral toxicity from imidacloprid and clothianidin seed treated sweet corn was not unexpected, as others have reported that pollen collected from seed treated maize (Schmuck et al., 2001) or imidacloprid seed treated sunflower (Schmuck and Keppler, 2003) contained residues below concentrations with no-observed effect on honey bees.

Compared to the chemicals studied, Bt was unique being the only control agent non-toxic by direct contact to honey bees. Sweet corn genetically engineered to express the Bt endotoxin Cry1 $\mathrm{AB}$ is as effective for ECB control as the registered insecticides (Bailey et al., 2005). Tassels and pollen from Bt sweet corn caused no significant honey bee toxicity in other larval feeding studies (EPA, 2000).

Heavy reliance on use of broad spectrum insecticides can have a serious impact on bees. Today pest control has evolved into Integrated Pest Management (IPM) which links management techniques with economic and environmental costs. Current tactics for sweet corn insect pest control do not include all of the necessary components of effective IPM. In particular, concerns have been raised regarding the potential impact on honey bees of carbofuran and imidacloprid. Our research shows that foliar applications of carbofuran applied for ECB control could be toxic to honey bees. Lambda-cyhalothrin, spinosad and Bt-sweet corn posed little to no risk. Imidacloprid and clothianidin, when used as seed corn treatments for CFB control pose no risk to honey bees foraging on the crop. These findings suggest that a management program for sweet corn insect pests that include these alternative control agents could be implemented to provide more effective IPM with reduced risk to honey bees.

\section{ACKNOWLEDGEMENTS}

The authors thank: the staff at the DRF and CRS, O. Welsh, P. Kelly, S. Hilton, D. McArthur, J. $\mathrm{McNeil}$ and K. Callow for assistance and expertise. This research was supported, in part, by the Ontario Food Processors' Association; Ontario Beekeepers' Association; Canadian Bee Research Fund; Agriculture and Agri-Food Canada; Dow AgroSciences Canada Inc.; NSERC-Industrial Post-Graduate Scholarship Fund; Ontario Ministry of Agriculture and Food (OMAF)-University of Guelph Plants Program and a OMAF Special Research Grant. Material donations were received from Syngenta CPC Inc., Bayer CropSciences Inc. and Gustafson Partnership LLC.

Résumé - Toxicité pour l'Abeille domestique (Apis mellifera), par voie orale et par contact, de produits autorisés dans la lutte contre les ravageurs du maïs doux en Ontario, Canada. Le carbofuran, la lambda-cyhalothrine, ou l'imidaclopride sont utilisés dans le sud-ouest de l'Ontario dans la lutte contre les deux ravageurs importants du maïs, la pyrale du maïs (Ostrinia nubilalis (Hübner)) et l'altise du maïs (Chaetocnema pulicaria (Melsheimer)). En période de pénurie les abeilles domestiques (Apis mellifera L.) sont susceptibles de butiner le maïs doux.

Les apiculteurs de l'Ontario ont connu des pertes substantielles d'abeilles, habituellement au cours d'années sèches, qu'ils ont attribuées au butinage des champs de maïs doux traités. Dernièrement, de nouveaux produits plus sélectifs sont apparus mais, avant leur adoption à grande échelle, il est important d'évaluer leur impact sur les abeilles domestiques. Nous avons mis au point des tests biologiques en laboratoire afin de comparer la toxicité orale et par contact vis-à-vis des abeilles des insecticides carbofuran, lambda-cyhalothrine et spinosad (application foliaire), de l'imidaclopride et la clothianidine (traitement des semences) et de maïs transgénique Bt. La clothianidine de qualité technique s'est révélée l'agent le plus toxique $(\mathrm{CL}=0,0002 \%)>$ carbofuran $(0,0010 \%)>$ imidaclopride $=$ spinosad $(0,0022 \%)$ $>$ lambda-cyhalothrine $(0,0031 \%)>$ Bacillus 
thuringiensis $(1,000 \%)$ (Tab. II). Des panicules de maïs doux traité au carbofuran ont entraîné une mortalité importante chez les abeilles jusqu'à 2 à 3 jours après le traitement (DAT) en 2002 et 2003 (Figs. 1, 2 et 3). Des panicules de maïs doux traité à la lambdacyhalothrine n'ont eu aucun impact sur les abeilles en 2002 ; en 2003, la toxicité était significativement plus élevée que le témoin non traité pour 1 DAT (Figs. 1, 2 et 3 ). Au cours de ces deux années, les panicules traités au spinosad ou issus de semences traitées à l'imidaclopride et à la clothianidine ou provenant de maïs doux Bt n'ont eu aucun impact sur la mortalité des abeilles (Figs. 1, 2 et 3). Lors d'essais oraux sur des abeilles naissantes, le pollen provenant de champs de maïs doux traité n'a eu aucun impact sur la mortalité des abeilles et ce, quel que soit le produit testé (Tab. III).

Ces études démontrent que, comparativement au carbofuran, la lambda-cyhalothrine, le spinosad, l'imidaclopride, la clothianidine et le maïs doux Bt, appliqués ou cultivés tel que recommandé, ne devraient avoir aucun impact sur les abeilles domestiques qui butinent les plantes traitées.

Apis mellifera / maïs doux / insecticide foliaire / traitement des semences / maïs doux-Bt / toxicité

Zusammenfassung - Kontakt- und orale Aufnahmetoxizität für Honigbienen (Apis mellifera) gegen Substanzen, die in Ontario, Kanada, für die Schädlingskontrolle in Süssmais zugelassen sind. Im Südwesten von Ontario wird im Süssmaisanbau Carbofuran, lambda-Cyhalothrin oder Saatgutbehandlung mit Imidacloprid zur Bekämpfung des Maiszünslers, Ostrinia nubilalis (Huebner), und des Maiserdflohs, Chaetocnema pulicaria (Melsheimer) eingesetzt. Süssmais ist normalerweise für Honigbienen nicht attraktiv, er kann jedoch in Dürreperioden zu einer wichtigen Pollenproteinquelle werden.

Hin und wieder haben Imker in Ontario nennenswerte Bienenverluste zu beklagen, und zwar typischerweise in trockenen Jahren und in Zusammenhang mit Insektizidspritzungen in Süssmais. Potentiell selektivere und effektive Bekämpfungsmethoden sind seit einiger Zeit in Untersuchung. Bevor sie jedoch in die Praxis Eingang finden können, müssen sie auf Bienenverträglichkeit überprüft werden. Wir haben Laborprüfungsmethoden entwickelt, mit denen die Kontaktgift- undFrassgiftwirkungen von heute zugelassenen Süssmais-Insektiziden mit denen von alternativen Bekämpfungsmitteln verglichen werden können. Die mittlere lethale Konzentration wurde in einem Direktkontakt-Test unter Verwendung eines Potter-Sprühturms für alle Testsubstanzen ermittelt. Technischer ClothianidinWirkstoff zeigte die höchste Toxizität (LC = $0,0002 \%)$, gefolgt von Carbofuran $(0,0010 \%)$, Imidacloprid und Spinosad $(0,0022 \%)$, lambda-Cyhalothrin $(0,0031 \%)$ und schliesslich Bacillus thuringiensis $(1,000 \%)$ (Tab. II). Bis zu 2 Tagen
(2002) oder 3 Tagen (2003) nach der Behandlung männlicher Blütenstände von Süssmais mit Carbofuran war eine signifikante Mortalität bei Bienen zu beobachten (Abb. 1, 2 und 3). Mit lambda-Cyhalothrin behandelte Süssmais-Blüten zeigten in 2002 keine nachteilige Wirkung auf Honigbienen; in 2003 war jedoch nach einem Tag eine im Vergleich zur Kontrolle signifikant erhöhte Mortalität festzustellen (Abb. 1, 2 und 3).

In beiden Versuchsjahren hatte die Spritzung mit Spinosad, die Beizung mit Imidacloprid bzw. Clothianidin oder die Ausbringung von transgenem $B t$-Süssmais keinen Einfluss auf die Mortalität von Honigbienen (Abb. 1, 2 und 3).

Die Verfütterung von behandeltem Pollen an frisch geschlüpfte Bienen führte bei keinem der geprüften Insektizide zu einer erhöhten Mortalität (Tab. III). Die vorliegenden Versuche zeigen, dass bei korrekter Applikation bzw. Anbau lambda-Cyhalothrin, Spinosad, Imidacloprid, Clothianidin und transgener $B t$-Süssmais, im Gegensatz zu Carbofuran, keinen negativen Einfluss auf Honigbienen haben, die in Insektizid-behandelten Süssmaisfeldern Pollen sammeln.

Apis mellifera / Süssmais / Insektizidspritzung / Saatgutbehandlung / Bt-Süssmais / Toxizität

\section{REFERENCES}

Abbott W.S. (1925) A method for computing the effectiveness of an insecticide, J. Econ. Entomol. 18, 265-267.

Andersch W., Schwarz M. (2003) Clothianidin seed treatment (Poncho) - The new technology for control of corn rootworms and secondary pests in UScorn production, Pflanzenschutz-Nachrichten Bayer 56, 147-172.

Atkins E.L., Kellum D., Atkins K.W. (1978) Integrated pest management strategies for protecting honey bees from pesticides, Am. Bee J. 118, 542548.

Bailey J.C., Scott-Dupree C.D., Tolman J.H., Harris C.R., Harris B.J. (2005) Alternative agents for control of European corn borer and corn flea beetle on Sweet Corn, J. Vegetable Sci. 11.

Burkness E.C., Hutchinson W.D., Bolin P.C., Bartels D.W., Warnock D.F., Davis D.W. (2001) Field efficacy of sweet corn hybrids expressing Bacillus thuringiensis toxin for management of Ostrinia nubilalis (Lepidoptera: Crambidae) and Helicoverpa zea (Lepidoptera: Noctuidae), J. Econ. Entomol. 94, 197-203.

Casteel D.B. (1912) The behavior of the honey bee in pollen collecting, USDA, Bur. Entomol. Bull. No. 121. 
Ditman L.P., Lloyd G.W. (1951) Timing treatments for European corn borer control, J. Econ. Entomol. $44,564-566$.

EPA (2000) Bt plant-pesticides, biopesticides registration action document, United States Environmental Protection Agency.

http://www.epa.gov/scipoly/sap/2000/october/ brad2_scienceassessment.pdf (accessed on 12 July 2005).

Flottum P.K., Erickson Jr. E.H., Hanny B.J. (1983) The honey bee - sweet corn relationship, Am. Bee J. 123, 293-299.

Halsall N., Gray A.P. (1998) Spinosad technical acute toxicity to honey bees (Apis mellifera), DowElanco Tech. Rep., pp. 8-13.

Harris C.R., Svec H.J. (1969) Laboratory studies on the contact toxicity of some insecticides to honeybees, Proc. Entomol. Soc. Ontario 100, 165-167.

Harrison F.P., Press J.W. (1971) Timing of insecticide applications for European corn borer control in sweet corn, J. Econ. Entomol. 64, 1496-1499.

Kuhar T.P., Stivers-Young L.J., Hoffman M.P., Taylor A.G. (2002) Control of flea beetle and Stewart's wilt in sweet corn with imidacloprid and thiamethoxam seed treatments, Crop Prot. 21, 25-31.

Mason C.E., Rice M.E., Calvin D.D., Van Duyn J.W., Showers W.B., Hutchison W.D., Witkowski J.F., Higgins R.A., Onstad D.W., Dively G.P. (1996) European corn borer ecology and management, North Central Regional Extension Publication No. 327, Iowa State University, Ames.

Mayer D.F., Kovacs G., Lunden J.D. (1998) Field and laboratory tests on the effects of cyhalothrin on adults of Apis mellifera, Megachile rotundata and Nomia melanderi, J. Apic. Res. 37, 33-37.

Munkvold G.P., McGee D.C., Iles A. (1996) Effects of imidacloprid seed treatment of corn on foliar feeding and Erwinia stewartii transmission by the corn flea beetle, Am. Phytopathol. Soc. 80, 747749.
Nowakowski J., Morse R.A. (1982) The behavior of honey bees in sweet corn fields in New York State, Am. Bee J. 122, 13-16.

Oliver S. (1999) Mediation Report Regarding Bee Kills in Southwestern Ontario, October 1999, Ontario Ministry of Agriculture and Food, 25 p.

Pataky J.K., Michener P.M., Freeman N.D., Weinzierl R.A., Teyker R.H. (2000), Control of Stewart's wilt in sweet corn with seed treatment insecticides, Plant Disease 84, 1104-1108.

Pepper E.H. (1967) Stewart's bacterial wilt of corn, Am. Phytopathol. Soc. Monogr. 4, 36.

Potter C. (1952) An improved laboratory apparatus for applying direct sprays and surface films, with data on the electrostatic charge on atomized spray fluids, Ann. Appl. Biol. 39, 1-28.

Schmuck R., Keppler J. (2003) Clothianidin - Ecotoxicological profile and risk assessment, Pflanzenschutz-Nachrichten Bayer 56, 26-58.

Schmuck R., Schooning R., Stork A., Schramel O. (2001) Risk posed to honey bees (Apis mellifera L., Hymenoptera) by an imidacloprid seed dressing on sunflowers, Pest Manage. Sci. 57, 225-238.

Scott-Dupree C.D., Spivak M.S. (2001) The impact of Gaucho and TI-435 seed treated canola on honey bees, Apis mellifera L. Report for Bayer CropScience Inc. 83 p.

[online] http://www.honeycouncil.ca/users/getdownload.asp?DownloadID $=83$ (accessed on 28 July 2005).

Scott-Dupree C.D., Callow K.A., Harris B.J. (2001) Efficacy of Success 480SC compared to Furadan $4 \mathrm{~F}$ and Ripcord 400EC against European corn borer in sweet corn, cv. Chippawa on sandy soil, Pest. Manage. Res. Report - 2000 Growing Season, Rep. No. 43, 96-97 [online] http://www.carccrac.ca/common/pmrr_2000.pdf (accessed 28 July 2005).

Stoner A., Wilson W.T., Rhodes H.A. (1982) Carbofuran: Effect of long-term feeding of low doses in sucrose syrup on honey bees in standard-size field colonies, Environ. Entomol. 11, 53-59. 